\title{
Pembangkit Listrik Tenaga Sampah: Antara Permasalahan Lingkungan dan Percepatan Pembangunan Energi Terbarukan
}

\author{
Waste to Energy Power Plant: Between Environmental Issue \\ and the Acceleration of Renewable Energy Development
}

\author{
Sri Nurhayati Qodriyatun \\ sri.qodriyatun@dpr.go.id \\ Pusat Penelitian, Badan Keahlian DPR RI \\ Jl. Jenderal Gatot Subroto, Senayan, Jakarta, 10270
}

Naskah diterima: 24 Februari 2021 | Naskah direvisi: 19 Mei 2021 | Naskah diterbitkan: 30 Juni 2021

\begin{abstract}
The government is trying to encourage the use of renewable energy, one of which is from waste to energy power plant. Efforts to accelerate the development of the plant are carried out through Presidential Regulation Number 35 of 2018. However, only one plant has been operating commercially since May 6th, 2021. This study aims to describe the development, the obstacles, and whether the plant is a solution to meet electricity needs or environmental problems. Through qualitative research, we found that the plant in Surabaya has been operating commercially; the plants in Surakarta and DKI Jakarta are in the construction stage; the plants in Palembang and Tangerang are in the stage of confirming the developer, and the rest are still on auction stage, PreFeasibility Study, Outline Business Case, or Final Business Case. The high tipping fee, limited local government budget, overestimation of potential for waste as electricity, limited competent human resources, the high selling price of the plant electricity, and no bankable guarantee for investment are obstacles to the plant development. The thermal plant is an instant solution for cities with above 1.000 ton/day waste and limited land for landfills. In the future, there should be regulatory support through the Renewable Energy Bill to overcome the obstacles. In addition, there should be a careful calculation of the energy potential of waste, a minimum budget allocation of 2-3\% for waste management and preparing capable human resources, providing adequate waste collection and transportation infrastructure, and educating the public on sorting waste.
\end{abstract}

Keywords: renewable energy; waste power plant; waste to energy

Abstrak: Pemerintah berupaya mendorong pemanfaatan energi terbarukan, salah satunya dengan membangun Pembangkit Listrik Tenaga Sampah (PLTSa). Upaya mempercepat pembangunan PLTSa dilakukan melalui Peraturan Presiden Nomor 35 Tahun 2018. Namun, hingga 6 Mei 2021 hanya satu PLTSa telah beroperasi secara komersial. Penelitian ini bertujuan mendeskripsikan perkembangan pembangunan PLTSa, kendala-kendala dan permasalahan pengembangannya, dan apakah PLTSa solusi pemenuhan kebutuhan listrik atau mengatasi masalah lingkungan. Melalui penelitian kualitatif, diketahui 1 PLTSa sudah beroperasi secara komersial (di Surabaya), 2 PLTSa dalam tahap konstruksi (di Surakarta dan DKI Jakarta), 2 PLTSa dalam tahap sudah ada pengembang (di Palembang dan Tangerang), dan sisanya masih dalam tahap lelang, Pre-Feasibility Study, Outline Business Case, atau Final 
Business Case. Lambatnya pembangunan PLTSa terjadi karena tingginya tipping fee, anggaran pemerintah daerah terbatas, over estimasi potensi listrik dari sampah, keterbatasan sumber daya manusia yang kapabel, tingginya harga jual listrik PLTSa, tidak adanya insentif bagi pengembang, dan tidak adanya jaminan bankable untuk investasi. PLTSa termal merupakan solusi instan mengatasi permasalahan lingkungan untuk kota dengan produksi sampah di atas 1.000 ton/hari dan keterbatasan lahan untuk TPA. Untuk itu, perlu ada dukungan regulasi melalui RUU EBT mengenai harga jual listrik PLTSa yang bersaing, insentif bagi pengembang PLTSa, dan jaminan bankable untuk investasi PLTSa. Selain itu, perlu ada perhitungan secara cermat potensi energi dari sampah, alokasi APBD minimal 2-3\% untuk pengelolaan sampah, dan menyiapkan sumber daya manusia yang kapabel, menyediakan sarana prasarana pengumpulan dan pengangkutan sampah yang memadai, dan mengedukasi masyarakat untuk memilah sampah.

Kata Kunci: energi terbarukan; pemanfaatan sampah untuk energi; PLTSa

\section{Pendahuluan}

Beberapa tahun terakhir, pemerintah semakin memberikan perhatian terhadap pembangunan pembangkit listrik tenaga sampah atau yang dikenal sebagai PLTSa. Besarnya perhatian pemerintah terlihat dari dikeluarkannya beberapa regulasi terkait pembangunan PLTSa, di antaranya Undang-Undang Nomor 30 Tahun 2007 tentang Energi (UU Energi) yang menjadi payung hukum pengembangan energi terbarukan dan ditindaklanjuti dengan Peraturan Pemerintah Nomor 79 Tahun 2014 tentang Kebijakan Energi Nasional (KEN) dan Peraturan Menteri Energi Sumber Daya Mineral (ESDM) Nomor 44 Tahun 2015 tentang Pembelian Tenaga Listrik oleh PT. Perusahaan Listrik Negara (Persero) dari Pembangkit Listrik Berbasis Sampah Kota. Dalam KEN dinyatakan bahwa sampah merupakan salah satu sumber energi terbarukan, dan pemanfaatan sampah untuk energi diarahkan untuk ketenagalistrikan dan transportasi. Undang-Undang Nomor 18 Tahun 2008 tentang Pengelolaan Sampah (UU Pengelolaan Sampah) yang menjadi payung hukum bagi pengelolaan sampah, juga mengatur bahwa sampah dapat dijadikan sumber energi.

Beberapa peraturan presiden juga dikeluarkan untuk mendorong pembangunan PLTSa. Pertama, Peraturan Presiden Nomor 3 Tahun 2016 tentang Percepatan
Pelaksanaan Proyek Strategis Nasional, yang menyebutkan pembangunan infrastruktur energi asal sampah di beberapa provinsi menjadi salah satu proyek strategis nasional. Kedua, Peraturan Presiden Nomor 18 Tahun 2016 tentang Percepatan Pembangunan Pembangkit Listrik Berbasis Sampah di Provinsi DKI Jakarta, Kota Tangerang, Kota Bandung, Kota Semarang, Kota Surakarta, Kota Surabaya, dan Kota Makassar. Peraturan Presiden ini kemudian dicabut dan digantikan dengan Peraturan Presiden Nomor 35 Tahun 2018 tentang Percepatan Pembangunan Instalasi Pengolah Sampah Menjadi Energi Listrik. Pembangunan PLTSa berdasarkan peraturan presiden ini yang kemudian dikenal sebagai program percepatan pembangunan PLTSa.

Regulasi lainnya terkait pengembangan PLTSa adalah Peraturan Menteri ESDM Nomor 50 Tahun 2017 tentang Pemanfaatan Sumber Energi Terbarukan untuk Penyediaan Tenaga Listrik juncto Peraturan Menteri ESDM Nomor 4 Tahun 2020 tentang Perubahan Kedua Peraturan Menteri ESDM Nomor 50 Tahun 2017 tentang Pemanfaatan Sumber Energi Terbarukan untuk Penyediaan Tenaga Listrik. Permen ESDM ini menjadi dasar bagi pengembangan PLTSa di luar program percepatan pembangunan PLTSa.

Pembangunan PLTSa, selain ditujukan sebagai alternatif sumber energi terbaru- 
kan, juga merupakan strategi yang ditetapkan pemerintah untuk mengatasi permasalahan lingkungan akibat sampah di banyak kota di Indonesia. Strategi tersebut tertuang dalam Lampiran II Peraturan Presiden Nomor 97 Tahun 2017 tentang Kebijakan dan Strategi Nasional Pengelolaan Sampah Rumah Tangga dan Sampah Sejenis Sampah Rumah Tangga.

Namun, rencana pembangunan PLTSa di beberapa daerah di Indonesia sempat mendapat tentangan, baik dari masyarakat maupun dari para aktivis lingkungan hidup. Keraguan akan munculnya dampak kesehatan dan lingkungan karena PLTSa menjadi pertimbangan aktivis lingkungan menentang dibangunnya PLTSa. Mereka juga mengkhawatirkan besarnya tipping fee yang harus dibayarkan nantinya (Indonesian Center for Environmental Law [ICEL], 2018; ICEL, 2019; Wibby, 2020; Wahana Lingkungan Hidup Indonesia [Walhi], 2018; Mantovani, 2020). Tipping fee adalah biaya yang dikeluarkan pemerintah selaku pemilik otoritas penanganan sampah maupun swasta pengelola kawasan kepada pengelola sampah atas biaya pembuangan sampah di tempat pengolahan akhir sampah. Besaran tipping fee umumnya didasarkan atas jumlah yang dikelola per ton atau satuan volume (Ekky, 2019: 3). Bahkan, Komisi Pemberantasan Korupsi (KPK) melalui kajiannya menyatakan bahwa pembangunan PLTSa yang direncanakan di 12 daerah itu akan membebani APBN sebesar Rp3,6 triliun setiap tahun selama 25 tahun, karena masa kontrak PLTSa adalah 25 tahun (Suparman, 2020). Pembangunan PLTSa di beberapa daerah di Indonesia menjadi terkesan dipaksakan di tengah upaya pemerintah memenuhi kebutuhan energi nasional dan pengembangan energi terbarukan.

Penelitian mengenai PLTSa sudah banyak dilakukan, baik dari aspek teknologi, aspek dampak lingkungan, aspek ekonomi, maupun aspek sosial pembangunan (Ikhsan \& Syukriyadin, 2014;
Faruq, 2016; Suhada \& Almahdy, 2017; Safrizal, 2014; Dodi, Syafii, \& Raharjo, 2015). Bahkan dalam penelitian Nurdiansah, Purnomo, dan Kasiwi (2020) disampaikan bahwa PLTSa dapat menjadi salah satu alternatif untuk mengurangi volume sampah. Namun, masih dibutuhkan sistem dan standardisasi operasi agar tidak menimbulkan kerusakan lingkungan sehingga dapat bekerja dengan baik dan efisien.

Hingga saat ini, belum ada penelitian yang mengkaji pembangunan PLTSa dari sisi pemenuhan energi listrik bagi masyarakat dan dari sisi pengurangan permasalahan lingkungan karena sampah. Pembangunan PLTSa diharapkan dapat memberikan sumbangan terhadap pemenuhan kebutuhan listrik masyarakat. Penelitian ini menjadi menarik karena produksi energi dari fosil mulai berkurang dan masyarakat global telah berkomitmen untuk mengurangi emisi Gas Rumah Kaca (GRK), termasuk Indonesia. Di sisi lain, beberapa kota di Indonesia sudah dalam kondisi darurat sampah. Menurut Heviati (2021a), pengelolaan sampah yang dilakukan dengan baik dan benar saat ini hanya 49,18\%. Sisanya yang $50,82 \%$, sampah langsung dibuang ke lingkungan 18,02\% dan ditangani di Tempat Pemrosesan Akhir (TPA) open dumping 32,8\%.

Praktik ini menyebabkan gangguan pada kehidupan masyarakat, karena sampah merupakan salah satu penyumbang GRK. GRK dihasilkan dari emisi karbondioksida (CO2) dan gas metana $(\mathrm{CH} 4)$ yang berasal dari sampah yang bertumpuk di TPA. Dalam Laporan Inventarisasi Gas Rumah Kaca dan Monitoring Pelaporan Verifikasi (MPV) Kementerian Lingkungan Hidup dan Kehutanan (KLHK) tahun 2018 disebutkan bahwa emisi GRK dari sektor persampahan (dalam laporan tersebut digunakan istilah limbah) terus meningkat setiap tahunnya (Tabel 1). Jika di tahun 2007 emisi GRK sektor persampahan tercatat 83,933 ribu ton $\mathrm{CO}_{2} \mathrm{e}$, di tahun 2017 meningkat menjadi 120,191 
ribu ton $\mathrm{CO}_{2} \mathrm{e}$ (BPS, 2019). Hal ini terjadi karena upaya pengurangan sampah melalui 3R (reduce, reuse, recycle) masih kurang dan belum semua TPA menerapkan sanitary landfill. Data tahun 2016-2017 menunjukkan jumlah kabupaten/kota dengan TPA open dumping sebanyak 167 dari 355 kabupaten/kota di Indonesia (Badan Pusat Statistik [BPS], 2018: vii). Masih tingginya emisi GRK Indonesia, termasuk dari sampah, menjadi tantangan bagi Pemerintah Indonesia untuk mewujudkan komitmen Indonesia mengurangi emisi GRK sebagaimana disebutkan dalam dokumen Nationally Determined Contribution/NDC (29\% tanpa syarat/dengan usaha sendiri dan $41 \%$ bersyarat/dengan dukungan internasional yang memadai pada tahun 2030) (KLHK, 2017: 1).

Tabel 1.

Emisi Gas Rumah Kaca di Indonesia dari sektor limbah, 2007 - 2017 (ribu ton $\mathrm{CO}_{2} \mathrm{e}$ )

\begin{tabular}{cc}
\hline Tahun & $\begin{array}{c}\text { Emisi GRK sektor limbah } \\
\text { (ribu ton } \mathbf{C O}_{2} \mathrm{e} \text { ) }\end{array}$ \\
\hline 2007 & 83,933 \\
2008 & 85,023 \\
2009 & 89,326 \\
2010 & 87,669 \\
2011 & 91,853 \\
2012 & 95,530 \\
2013 & 100,515 \\
2014 & 102,834 \\
2015 & 106,061 \\
2016 & 112,351 \\
2017 & 120,191 \\
\hline
\end{tabular}

Sumber: Laporan Inventarisasi Gas Rumah Kaca dan MPV 2018, KLHK (BPS, 2019)

Berdasarkan latar belakang tersebut, maka permasalahannya adalah apakah pembangunan PLTSa dapat memenuhi kebutuhan listrik masyarakat dan dapat mengurangi permasalahan lingkungan akibat sampah? Penelitian fokus pada pembangunan PLTSa berdasarkan program percepatan mengacu pada Peraturan Presiden Nomor 35 Tahun 2018. Adapun pertanyaan penelitiannya adalah: (1) bagaimana perkembangan pembangun- an PLTSa selama ini di tengah upaya Pemerintah mempercepat pembangunan energi terbarukan?; (2) apa kendala dan permasalahan dalam pengembangan PLTSa?; (3) apakah PLTSa dapat menjadi salah satu sumber energi listrik yang menjanjikan sebagaimana sumber energi terbarukan lainnya atau hanya solusi untuk menyelesaikan permasalahan lingkungan akibat sampah?

Penelitian dilakukan pada tahun 2020 dengan menggunakan metode kualitatif. Data dikumpulkan melalui beberapa teknik pengumpulan data, yaitu: wawancara, focus group discussion (FGD), observasi lapangan, studi literatur dengan membatasi diri pada jurnal dan buku yang berisi perkembangan teknologi pemanfaatan sampah untuk energi (Waste to Energy/WtE), dan mengikuti webinar terkait pengembangan PLTSa. Data kegiatan wawancara, FGD, dan observasi didapat dari kegiatan dalam penelitian pada Pusat Penelitian Badan Keahlian DPR RI mengenai Optimalisasi Pengembangan Energi Baru Terbarukan pada tahun 2020, di mana peneliti merupakan anggota dalam tim penelitian tersebut.

Tabel 2.

Data yang Dikumpulkan

\begin{tabular}{cll}
\hline No & \multicolumn{1}{c}{ Data } & \multicolumn{1}{c}{ Metode } \\
\hline 1. & $\begin{array}{l}\text { Pemanfaatan sampah } \\
\text { untuk energi (WtE) }\end{array}$ & $\begin{array}{l}\text { Webinar, FGD, } \\
\text { wawancara, } \\
\text { studi literatur }\end{array}$ \\
\hline 2. & $\begin{array}{l}\text { Perkembangan teknologi } \\
\text { WtE }\end{array}$ & $\begin{array}{l}\text { Studi literatur, } \\
\text { webinar }\end{array}$ \\
\hline 3. & $\begin{array}{l}\text { Perkembangan PLTSa di } \\
12 \text { kota sesuai Perpres } \\
\text { 35/2018 }\end{array}$ & $\begin{array}{l}\text { Webinar, } \\
\text { Wawancara, } \\
\text { FGD }\end{array}$ \\
\hline 4. & Kendala pengembangan \\
& PLTSa di 12 Kota & Wawancara, \\
\hline
\end{tabular}

Tim mewawancarai Dr. Ir. Widiatminingsih Winanti, M.Si (peneliti Badan Pengkajian dan Penerapan Teknologi [BPPT] dan koordinator operasional PLTSa Bantar Gebang), Kusmawatiningsih (pejabat di Dinas Lingkungan Hidup Kota Bekasi), 
dan Rakhmadi Kusumo (pengembang pembangkit listrik dari energi terbarukan). FGD dilakukan dengan Dr. Surya Darma (Ketua Umum Masyarakat Energi Terbarukan Indonesia [METI]), Prof. Dr. Priyono Sutikno (Ketua Pusat Studi Pengembangan EBT-ITB), Prof. Dr. Rinaldy Dalimi (Dewan Energi Nasional). Studi literatur memfokuskan pada hasil-hasil penelitian tentang pengembangan teknologi WtE yang diterbitkan oleh jurnal nasional maupun internasional dan peraturan perundang-undangan terkait pengembangan PLTSa dan kebijakan energi terbarukan. Untuk menambah informasi, penulis juga mengikuti webinar yang fokus membahas pembangunan PLTSa di Indonesia, yaitu: webinar Prospek Pengolahan Sampah Menjadi Energi Listrik di Indonesia (1 September 2020) dan webinar Pembangkit Listrik Tenaga Sampah (PLTSa): Tantangan, Kendala, dan Peluang (6 Februari 2021). Sementara itu, data observasi diperoleh saat kunjungan Tim ke PLTSa Bantar Gebang untuk melihat bagaimana proses pengolahan sampah di TPST Bantar Gebang menjadi listrik. Data di atas kemudian diolah dengan mengelompokkan data terlebih dahulu berdasarkan permasalahan penelitian, kemudian dilakukan analisis secara deskriptif berdasarkan data yang terkumpul sesuai pertanyaan penelitian yang diajukan.

\section{Pembangkit Listrik Tenaga Sampah (PLTSa)}

Pemanfaatan sampah untuk menjadi energi (Waste to Energy [WtE]) sudah banyak dilakukan, salah satunya untuk pembangkit listrik. Pembangkit listrik tenaga sampah dikenal sebagai PLTSa. Teknologi pemanfaatan sampah untuk menghasilkan energi listrik sudah banyak dikembangkan. Secara prinsip, proses sampah diubah menjadi energi listrik dilakukan melalui proses pembakaran langsung (direct combustion) atau pun tidak langsung (melalui proses konversi) (Bagan 1). Ada tiga proses konversi sampah menjadi energi: melalui thermo- chemical, physicochemical, atau biochemical (Nizami et al., 2017: 1105; Ali et al., 2020: 2). Teknologi yang menggunakan proses konversi thermochemical antara lain: Torrefaction (torefaksi), Plasma treatment, Gasification (gasifikasi), Pyrolysis (pemanasan), dan Liquefaction (pelarutan) yang akan menghasilkan bahan bakar dalam bentuk padat atau cair. Teknologi yang menggunakan proses konversi physicochemical adalah extraction (ekstraksi), yang nantinya menghasilkan bahan bakar dalam bentuk cair. Sementara itu, teknologi yang menggunakan proses biochemical, antara lain: fermentation (fermentasi) dan Anaerobic Digestion (AD atau Biodigester) yang menghasilkan bahan bakar dalam bentuk gas (Bagan 1). Bahan bakar inilah yang nantinya digunakan untuk menghasilkan energi panas yang akan menggerakkan turbin generator yang menghasilkan listrik (Kaltschmitt \& Reinhardt, 1997, dalam Bosmans \& Helsen, 2010: 3).

Di luar itu, pemanfaatan sampah untuk energi bisa juga dilakukan melalui pemanfaatan gas metana di TPA (landfill gas utilization) dan biorefinery (Ali et al., 2020: 2). Berdasarkan reviu Willumsen (2003, dalam Themelis \& Ulloa, 2005: 1) dilaporkan bahwa dari 2.001 pembangkit listrik yang memanfaatkan sampah sebagai bahan bakunya, 955 di antaranya landfill gas utilization. Pembangkit listrik dengan landfill gas utilization terbanyak berada di Amerika Serikat, yaitu sebanyak 325 pembangkit. Sementara itu, teknologi biorefinery merupakan teknologi mengubah sampah untuk menjadi berbagai macam bahan bakar (fuel), energi, dan bahan-bahan kimia lainnya yang banyak dimanfaatkan dalam kehidupan (Kokossis, Tsakalova, \& Pyrgakis, 2015). Salah satu produk yang dihasilkan dengan menggunakan teknologi biorefinery adalah refuse derived fuel (RDF), yaitu: bahan bakar yang berasal dari sampah yang mudah terbakar yang diolah melalui proses pencacahan, pengayakan, dan klasifikasi udara (Liu, Paode, \& Holsen, 1996, dalam Hutabarat dkk., 2018: 


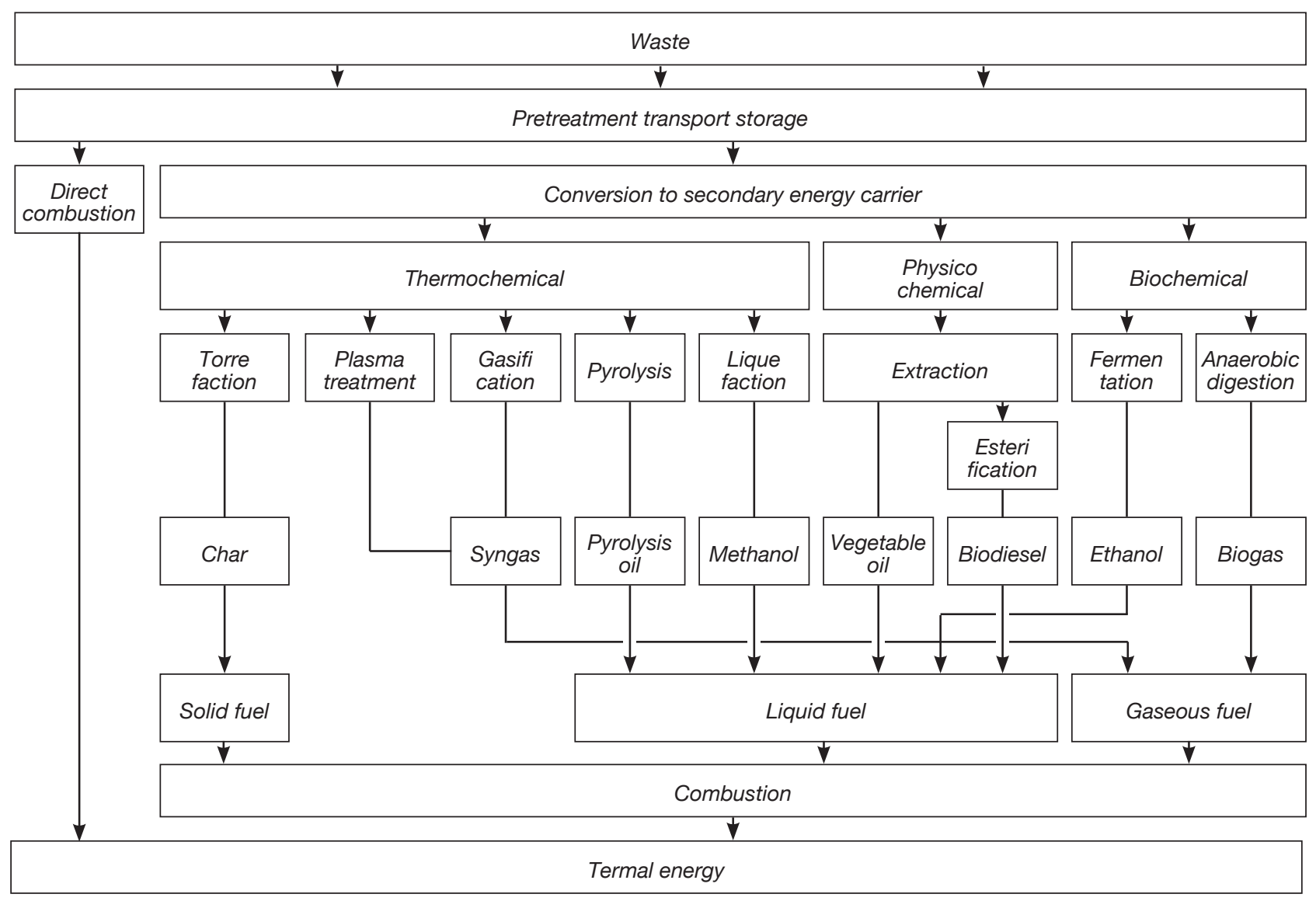

Bagan 1.

Teknologi dalam Waste to Energy

Sumber: Kaltschmitt \& Reinhardt, 1997, dalam Bosmans \& Helsen (2010)

25). RDF merupakan salah satu teknik penanganan sampah yang lebih kompleks dibandingkan teknologi insinerasi dan AD (Nizami et al., 2017: 1105).

Masing-masing teknologi memiliki kelebihan dan kekurangan. Tabel 3 memperlihatkan kelebihan dan kekurangan dari teknologi insinerasi, pirolisis, gasifikasi, RDF, dan AD menurut Nizami et al. (2017). Pada Tabel 3 terlihat bahwa insinerasi dinilai cukup efektif untuk mengurangi volume sampah hingga 80\%. Akan tetapi, insinerasi yang dibangun di dekat permukiman perkotaan banyak mendapat tentangan publik (Mubeen \& Buekens, 2019) karena proses pembakaran dalam kebanyakan teknologi insinerasi menghasilkan emisi GRK seperti carbon monoxide, sulfur dioxide, hydrogen chloride, hydrogen fluoride, nitrogen oxide, organic carbon, dan logam berat radikal (Ashworth, Elliot, \& Toledano, 2014). PLTSa dengan insinerasi merupakan solusi instan untuk kota yang tidak lagi mempunyai lahan untuk menampung sampahnya, seperti di Bangladesh (Hossain, Hossain, Mounir, \& Ahmed, 2014) dan Uni Emirat Arab (Paleologos, Caratelli, \& Amrousi, 2016). Teknologi pirolisis juga efektif untuk mengurangi volume sampah hingga 90\%, namun teknologi ini sangat rumit, membutuhkan sumber daya manusia (SDM) yang terampil, dan paling tidak efisien untuk menghasilkan energi listrik. Teknologi gasifikasi adalah yang paling aman bagi lingkungan, karena tidak ada emisi GRKnya. Sayangnya, teknologi ini membutuhkan modal yang besar. Sementara itu, teknologi RDF mempunyai nilai energi tinggi, namun hasil pembakaran pelet RDF menimbulkan polusi udara. Perlu ada penanganan abu dari hasil pembakaran pelet RDF. Sementara itu, teknologi $A D$ adalah teknologi yang paling murah dibanding yang lain. Hanya saja, teknologi 
Tabel 3.

Kekurangan dan Kelebihan Teknologi Insinerasi, Pirolisis, Gasifikasi, RDF, dan AD untuk Menghasilkan Energi Listrik

\begin{tabular}{|c|c|c|c|c|}
\hline Insinerasi & Pirolisis & Gasifikasi & RDF & AD \\
\hline \multicolumn{5}{|l|}{ Sampah yang sesuai } \\
\hline Semua jenis sampah & $\begin{array}{l}\text { Sampah organik dan } \\
\text { anorganik }\end{array}$ & $\begin{array}{l}\text { Sampah organik dan } \\
\text { anorganik }\end{array}$ & $\begin{array}{l}\text { Semua sampah } \\
\text { kecuali yang } \\
\text { mengandung protein } \\
\text { tinggi }\end{array}$ & Sampah organik \\
\hline \multicolumn{5}{|l|}{ Kelebihan } \\
\hline $\begin{array}{l}\text { - Mengurangi volume } \\
\text { sampah hingga } \\
80 \% \text {. } \\
\text { - Mengurangi massa } \\
\text { sampah hingga } \\
70 \% \text {. } \\
\text { - Sebagian besar } \\
\text { sampah padat kota } \\
\text { diolah. } \\
\text { - Pengaturan mudah } \\
\text { dan perawatan } \\
\text { cepat. }\end{array}$ & $\begin{array}{l}\text { - Energi hingga } \\
80 \% \text { didapat dari } \\
\text { sampah. } \\
\text { - Pembebasan lahan } \\
\text { berkurang. } \\
\text { - Produk energi } \\
\text { tinggi. } \\
\text { - Produk dalam } \\
\text { bentuk gas dan cair } \\
\text { mudah dipisahkan. } \\
\text { - Volume sampah } \\
\text { padat kota } \\
\text { berkurang } 50-90 \% .\end{array}$ & $\begin{array}{l}\text { - Tidak emisi GRK. } \\
\text { - Semua sampah } \\
\text { terolah. } \\
\text { - Teknologinya } \\
\text { mudah } \\
\text { dikembangkan. }\end{array}$ & $\begin{array}{l}\text { - Sampah stabil. } \\
\text { - Ukuran sampah } \\
\text { berkurang. } \\
\text { - Nilai energi tinggi } \\
\text { dari RDF. }\end{array}$ & $\begin{array}{l}\text { - Sampah padat } \\
\text { berkurang } \\
\text { - Menghasilkan } \\
\text { biogas dengan } \\
\text { energi tinggi } \\
\text { - Pupuk organik } \\
\text { yang dihasilkan } \\
\text { kaya nutrisi } \\
\text { - Teknologinya } \\
\text { murah }\end{array}$ \\
\hline \multicolumn{5}{|l|}{ Kekurangan } \\
\hline $\begin{array}{l}\text { - Polusi udara. } \\
\text { - Melepaskan dioxin. } \\
\text { - Modal besar. } \\
\text { - Penolakan publik. } \\
\text { - Menghasilkan } \\
\text { limbah padat } \\
\text { berbahaya (slag). }\end{array}$ & $\begin{array}{l}\text { - Produk tidak } \\
\text { bersih. } \\
\text { - Hasil produk cair } \\
\text { rendah. } \\
\text { - Menyisakan kokas } \\
\text { (arang sisa). } \\
\text { - Perlu pembersihan } \\
\text { produk. } \\
\text { - Korosi tabung. } \\
\text { - Input energi tinggi. } \\
\text { - Operasional dan } \\
\text { biaya perawatan } \\
\text { mahal. }\end{array}$ & $\begin{array}{l}\text { - Input energi tinggi. } \\
\text { - Modal dan } \\
\text { operasional besar. }\end{array}$ & $\begin{array}{l}\text { - Pelet RDF } \\
\text { menyebabkan } \\
\text { polusi udara ketika } \\
\text { digunakan di } \\
\text { pembangkit listrik. } \\
\text { - Penanganan abu } \\
\text { yang dihasilkan di } \\
\text { pembangkit mahal. } \\
\text { - Memerlukan tanah } \\
\text { dengan syarat } \\
\text { tertentu (mahal). }\end{array}$ & $\begin{array}{l}\text { - Kotor. } \\
\text { - Tidak untuk } \\
\text { pembangkit skala } \\
\text { besar. } \\
\text { - Stabilitas sistem } \\
\text { rendah. } \\
\text { - Membutuhkan } \\
\text { ruang ekstra. }\end{array}$ \\
\hline \multicolumn{5}{|c|}{ Biaya tahunan per ton sampah (dalam US\$) } \\
\hline $14,5-22$ & 17-25 & $19,5-30$ & $7,5-11,3$ & $0,1-0,14$ \\
\hline \multicolumn{5}{|c|}{ Biaya net operasional per ton sampah (dalam US\$) } \\
\hline $1,5-2,5$ & $2-3$ & $2,5-4$ & 0,3-055 & Minimal \\
\hline \multicolumn{5}{|c|}{ Daya harian (MW per ton sampah) } \\
\hline $0,01-0,02$ & $0,01-0,014$ & $0,04-0,045$ & $0,01-0,014$ & $0,015-0,02$ \\
\hline \multicolumn{5}{|c|}{ Kompleksitas teknologi } \\
\hline Rendah & Tinggi & Sangat tinggi & Sedang & Rendah \\
\hline \multicolumn{5}{|c|}{ Keterampilan tenaga kerja } \\
\hline Rendah & Sedang & Sangat tinggi & Tinggi & Rendah \\
\hline \multicolumn{5}{|l|}{ Lokasi } \\
\hline Perkotaan & $\begin{array}{l}\text { Kawasan industri } \\
\text { perkotaan }\end{array}$ & Perkotaan & $\begin{array}{l}\text { Perkotaan dan } \\
\text { kawasan industri }\end{array}$ & Pedesaan \\
\hline $25 \%$ & $17 \%$ & $32 \%$ & $18 \%$ & $25-30 \%$ \\
\hline
\end{tabular}

Sumber: Nizami et al. (2017) 
ini tidak bisa digunakan untuk pembangkit listrik skala besar. Dari berbagai teknologi pemanfaatan sampah untuk energi yang dikembangkan, menurut Gomez et al. (2010, dalam Nizami et al., 2017: 1105), insinerasi menjadi teknologi yang direkomendasikan untuk pembangkit listrik dibandingkan teknologi lainnya. Namun, perlu tambahan teknologi untuk mengendalikan polusi yang dihasilkan (bottom ash dan fly ash).

\section{Kebijakan Pengembangan PLTSa}

Kebijakan pengembangan PLTSa sebenarnya ada dua. Pertama, kebijakan pengembangan PLTSa berdasarkan Peraturan Presiden Nomor 35 Tahun 2018. Selanjutnya kebijakan ini disebut sebagai program percepatan pengembangan PLTSa. Kedua, kebijakan pengembangan PLTSa berdasarkan Peraturan Menteri ESDM Nomor 50 Tahun 2017 tentang Pemanfaatan Sumber Energi Terbarukan untuk Penyediaan Tenaga Listrik juncto Peraturan Menteri ESDM Nomor 4 Tahun 2020 tentang Perubahan Kedua Peraturan Menteri ESDM Nomor 50 Tahun 2017 tentang Pemanfaatan Sumber Energi Terbarukan untuk Penyediaan Tenaga Listrik. Selanjutnya, kebijakan ini disebut sebagai program reguler pengembangan PLTSa.

Perbedaan prinsip dari kedua program tersebut adalah penggunaan teknologi dalam PLTSa, harga pembelian listrik, dan dukungan pemerintah pusat terhadap pembayaran Tipping Fee atau Biaya Layanan Pengolahan Sampah (BLPS) (Tabel 4). Teknologi yang harus diterapkan dalam program percepatan PLTSa adalah teknologi termal, sedangkan untuk program reguler pengembangan PLTSa dapat dilakukan dengan menggunakan teknologi termal ataupun nontermal.

Pemilihan penggunaan teknologi dalam pengembangan PLTSa ini sejalan dengan strategi pemanfaatan sampah untuk energi seperti yang disebutkan dalam Jakstranas Pengelolaan Sampah Rumah Tang- ga dan Sampah Sejenis Sampah Rumah Tangga (Peraturan Presiden Nomor 97 Tahun 2017). Dalam Perpres tersebut pemanfaatan sampah untuk energi dilakukan melalui strategi: (1) pembangunan pembangkit listrik berbasis sampah melalui teknologi termal; (2) penangkapan dan pemanfaatan gas metana menjadi sumber energi listrik di TPA; (3) pemanfaatan sampah menjadi bahan bakar substitusi industri semen atau RDF; (4) penerapan teknologi pemilahan, pengumpulan, pengolahan, dan pemrosesan akhir yang ramah lingkungan menjadi energi terbarukan. Strategi pertama menjadi dasar program percepatan pengembangan PLTSa. Strategi kedua, ketiga, dan keempat menjadi dasar pengembangan PLTSa program reguler.

Adapun yang melatarbelakangi kebijakan pengembangan PLTSa adalah: (1) persoalan sampah telah menjadi masalah lingkungan karena menghasilkan gas metana $(\mathrm{CH} 4)$ dan karbondioksida (CO2); (2) adanya keterbatasan lahan dan daya tampung TPA di beberapa daerah yang telah berkembang menjadi kota besar; (3) Pemerintah Indonesia mempunyai komitmen untuk mengurangi emisi GRK sebesar 29\% dari BAU (business as usual) pada tahun 2030; (4) Pemerintah sedang berupaya untuk mengurangi penggunaan energi fosil pada pembangkit listrik dan meningkatkan ketersediaan pasokan listrik nasional; (5) sampah mempunyai potensi energi biomassa yang dapat dikonversi menjadi energi lain seperti untuk energi listrik atau menjadi bahan bakar; (6) perlu ada upaya untuk mengurangi volume sampah yang tidak terkelola dengan baik; (7) PLTSa dengan teknologi termal dapat diimplementasikan di seluruh daerah dengan volume sampah yang besar dan yang mengalami darurat sampah; (8) melalui pembangunan PLTSa dapat meningkatkan kebersihan dan kesehatan masyarakat (Heviati, 2021b). Teknologi termal dipilih dengan pertimbangan dapat mengurangi volume sampah dengan cepat 
Tabel 4.

Perbedaan Kebijakan Program Percepatan dan Program Reguler Pengembangan PLTSa

\begin{tabular}{|c|c|c|c|}
\hline No & $\begin{array}{l}\text { Subjek yang } \\
\text { Diatur }\end{array}$ & $\begin{array}{l}\text { Program Percepatan } \\
\text { Pengembangan PLTSa }\end{array}$ & Program PLTSa Reguler \\
\hline 1. & Dasar hukum & $\begin{array}{l}\text { - Perpres 58/2017 tentang Proyek } \\
\text { Strategis Nasional. } \\
\text { - Perpres 35/2018 tentang Proyek } \\
\text { Percepatan Pembangunan PLTSa. }\end{array}$ & $\begin{array}{l}\text { Permen ESDM 50/2017 ju Permen ESDM } \\
\text { 4/2020 tentang Pemanfaatan Energi } \\
\text { Terbarukan untuk Penyediaan Tenaga } \\
\text { Listrik. }\end{array}$ \\
\hline 2. & Lokasi & $\begin{array}{l}12 \text { kota: DKI Jakarta, Bandung, } \\
\text { Tangerang Selatan, Tangerang, Bekasi, } \\
\text { Semarang, Surakarta, Surabaya, } \\
\text { Palembang, Denpasar, Makassar, } \\
\text { Manado. }\end{array}$ & $\begin{array}{l}\text { Semua wilayah di Indonesia, kecuali } \\
12 \text { kota yang terdaftar dalam proyek } \\
\text { percepatan pembangunan PLTSa. }\end{array}$ \\
\hline 3. & Teknologi & Proven-thermal & Proven-Thermal \& Non-thermal \\
\hline 4. & $\begin{array}{l}\text { Dukungan } \\
\text { Pemerintah }\end{array}$ & $\begin{array}{l}\text { Pemerintah Pusat memberikan dukungan } \\
\text { pendanaan tipping fee (maksimum } 49 \% \\
\text { dari total tipping fee). }\end{array}$ & $\begin{array}{l}\text { Pemerintah Pusat tidak menyediakan } \\
\text { dukungan pendanaan untuk tipping fee. }\end{array}$ \\
\hline 5. & Periode PJBL & 20 tahun sejak COD. & 20 tahun sejak COD. \\
\hline 6. & $\begin{array}{l}\text { Harga } \\
\text { Pembelian } \\
\text { Listrik }\end{array}$ & $\begin{array}{l}\text { - Untuk kapasitas } \leq 20 \mathrm{MW}=\text { US\$13,35 } \\
\text { cent/kWh. } \\
\text { - Untuk kapasitas } \geq 20 \mathrm{MW}=14,54- \\
\text { (0,076 x kapasitas kontrak). }\end{array}$ & 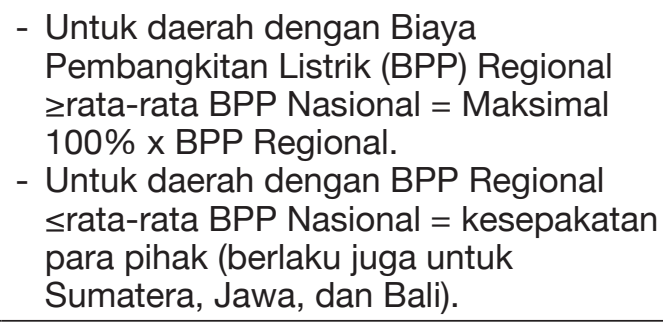 \\
\hline 7. & $\begin{array}{l}\text { Ketentuan } \\
\text { tentang harga }\end{array}$ & $\begin{array}{l}\text { - Tanpa negosiasi. } \\
\text { - Tanpa eskalasi. } \\
\text { - Berlaku setelah COD. }\end{array}$ & $\begin{array}{l}\text { - Menggunakan harga referensi, } \\
\text { negosiasi dengan PLN dimungkinkan. } \\
\text { - Tanpa eskalasi. } \\
\text { - Berlaku setelah COD. }\end{array}$ \\
\hline
\end{tabular}

Sumber: Misna (2020)

dan berpotensi untuk menghasilkan energi listrik (Heviati, 2021a; Winanti, wawancara, 23 Oktober 2020).

Kementerian ESDM telah memperhitungkan potensi listrik yang akan dihasilkan dari pemanfaatan sampah dengan mengacu data jumlah sampah dalam Sistem Informasi Pengelolaan Sampah. Berdasarkan data sistem tersebut, jumlah sampah yang ditimbun di TPA 864.469 ton/hari dan yang tidak terkelola mencapai 3.964.946 ton/hari. Jumlah per tahunnya untuk sampah yang ditimbun di TPA mencapai 315.531.101 ton/tahun dan yang tidak terkelola mencapai 1.447.205.389 ton/tahun. Potensi listrik dari sampah jika diasumsikan 100 ton sampah menghasilkan $1 \mathrm{MW}$, maka untuk sampah yang ditimbun di TPA diperkirakan akan meng- hasilkan $8.645 \mathrm{MW}$ dan dari sampah yang tidak terkelola diperkirakan akan menghasilkan 39.649 MW (Misna, 2020). Untuk 12 daerah yang masuk dalam program percepatan pembangunan PLTSa-yaitu: Provinsi DKI Jakarta, Kota Tangerang, Kota Tangerang Selatan, Kota Bekasi, Kota Bandung, Kota Semarang, Kota Surakarta, Kota Surabaya, Kota Makassar, Kota Denpasar, Kota Palembang, dan Kota Manado-diperkirakan sampah yang akan diolah mencapai \pm 16.000 ton/hari dan kapasitas listrik yang akan dibangkitkan mencapai antara $170 \mathrm{MW}$ hingga 240 MW (Heviati, 2021b). Potensi yang cukup besar inilah yang mendorong pemerintah untuk mempercepat pembangunan PLTSa. Selain sebagai solusi untuk mengatasi permasalahan sampah yang sudah dalam 
Tabel 5.

Perkembangan Proyek Percepatan PLTSa Berdasarkan

Peraturan Presiden Nomor 35 Tahun 2018

\begin{tabular}{|c|c|c|c|c|c|c|}
\hline No & Daerah & $\begin{array}{c}\text { Volume } \\
\text { Sampah yang } \\
\text { Diperlukan } \\
\text { (Ton/Hari) }\end{array}$ & $\begin{array}{c}\text { Listrik } \\
\text { yang } \\
\text { Dihasilkan } \\
\text { (MW) }\end{array}$ & Pengembang & Teknologi & Progres \\
\hline 1. & DKI Jakarta & \pm 2.200 & 35 & $\begin{array}{l}\text { PT. Jakarta } \\
\text { Solusi Lestari }\end{array}$ & Incinerator & Sudah PJBL, tahap pendanaan. \\
\hline 2. & Surakarta & \pm 450 & 10 & $\begin{array}{l}\text { PT. Solo Citra } \\
\text { Metro Plasma } \\
\text { Power }\end{array}$ & $\begin{array}{l}\text { Pyrolysis } \\
\text { Gasifikasi }\end{array}$ & $\begin{array}{l}\text { Sudah PJBL, tahap konstruksi, COD } \\
\text { target } 2022\end{array}$ \\
\hline 3. & Surabaya & $\pm 1.400-1.500$ & 9 & $\begin{array}{l}\text { PT. Sumber } \\
\text { Organik }\end{array}$ & Gasifikasi & COD per 6 Mei 2021* \\
\hline 4. & Palembang & \pm 1.200 & $10-20$ & & - & Sudah ada pengembang \\
\hline 5. & Tangerang & \pm 2.000 & $10-20$ & & - & Sudah ada pengembang \\
\hline 6. & Bandung & \pm 1.820 & $21-29$ & & - & Persiapan Lelang, Pra-FS/OBC/FBC \\
\hline 7. & Tangsel & \pm 1.000 & $10-20$ & & - & Persiapan Lelang, Pra-FS/OBC/FBC \\
\hline 8. & Bekasi & \pm 2.200 & $10-20$ & & - & Persiapan Lelang, Pra-FS/OBC/FBC \\
\hline 9. & Manado & \pm 1.000 & $15-20$ & & - & Persiapan Lelang, Pra-FS/OBC/FBC \\
\hline 10. & Makassar & \pm 1.400 & $15-20$ & & - & Persiapan Lelang, Pra-FS/OBC/FBC \\
\hline 11. & Denpasar & \pm 1.200 & $15-20$ & & - & Persiapan Lelang, Pra-FS/OBC/FBC \\
\hline 12. & Semarang & \pm 1.000 & $10-20$ & & - & Persiapan Lelang, Pra-FS/OBC/FBC \\
\hline
\end{tabular}

Keterangan:

Sumber: Heviati (2021b), Dewi (2021)

PJBL : Perjanjian Jual Beli Listrik

Pra-FS : Pre-Feasibility Study (Prastudi Kelayakan)

OBC : Outline Business Case (Kajian Awal Prastudi Kelayakan)

FBC : Final Business Case (Kajian Akhir Prastudi Kelayakan)

* Pada tanggal 6 Mei 2021 PLTSa Benowo diresmikan beroperasi secara komersial (Meilanova, 2021).

kondisi darurat, juga dapat memberikan sumbangan bagi penyediaan listrik di masyarakat.

Dalam kebijakan percepatan pengembangan PLTSa, pemerintah pusat maupun pemerintah daerah memiliki tugas dan kewajiban masing-masing. Pertama, Kementerian ESDM bertugas menetapkan harga dan formula untuk pembelian tenaga listrik oleh PT PLN (Persero). Selain itu, menugaskan PLN untuk membeli tenaga listrik yang dihasilkan PLTSa. Harga beli listrik PLTSa oleh PLN untuk kapasitas produksi listrik hingga $20 \mathrm{MW}$ adalah US\$13,35 cent/kWH dan untuk kapasitas di atas $20 \mathrm{MW}$ adalah US\$4,54 cent $/ \mathrm{kWh}$ - (0,076 x kapasitas PLTSa) (Dewi, 2021). Kedua, Kementerian Keuangan mengalokasikan dana untuk memberikan bantuan
BLPS/Tipping Fee dalam bentuk subsidi/ kompensasi kepada pemerintah daerah, paling tinggi Rp500.000,00/ton sampah. Ketiga, pemerintah daerah (pemerintah kota/kabupaten atau pemerintah provinsi) dapat menugaskan BUMD, melakukan kompetisi badan usaha, atau mengusulkan kepada Menteri ESDM untuk menugaskan BUMN sebagai pengembang PLTSa. Selain itu, pemerintah daerah wajib melakukan Pre-Feasibility Study (Pra-FS), menjamin ketersediaan feedstock sesuai Pra-FS, memastikan ketersediaan lokasi pembangunan PLTSa dalam Rencana Tata Ruang Wilayah Provinsi/Kabupaten/Kota, dan berkomitmen untuk mengalokasikan dana untuk BLPS (Misna, 2020).

Besarnya perhatian pemerintah pusat terhadap program percepatan pengem- 
bangan PLTSa diharapkan segera mewujudkan pembangunan PLTSa di 12 daerah. Adanya dukungan dana Tipping Fee maksimal 49\% dari besaran biaya Tipping Fee yang disepakati antara pengembang PLTSa dengan pemerintah daerah diharapkan dapat mengurangi beban APBD. Selain itu, adanya kepastian listrik dibeli oleh PLN dengan harga yang lebih tinggi dibandingkan harga listrik pembangkit lainnya diharapkan menjadikan PLTSa program percepatan menarik bagi investor. Bahkan, harga beli listrik program percepatan dihargai lebih tinggi dibandingkan harga beli listrik PLTSa program reguler.

\section{Perkembangan Pembangunan PLTSa}

Pada kenyataannya, perkembangan program percepatan pembangunan PLTSa di 12 daerah di Indonesia berjalan lambat. Dari tahun 2018 hingga 6 Mei 2021, hanya ada satu PLTSa yang sudah beroperasi secara komersial (Commercial Operation Date/COD). Pada Tabel 5 dapat dilihat, satu PLTSa di Surabaya COD per 6 Mei 2021 dan dua PLTSa sudah tahap Perjanjian Jual Beli Listrik (PJBL), yaitu di Provinsi DKI Jakarta dan Kota Surakarta. Pembelian tenaga listrik PLTSa Putri Cempo Kota Surakarta oleh PLN dengan harga US\$13,35 cent/kWh untuk kapasitas $5 \mathrm{MW}$. Untuk PLTSa Sunter DKI Jakarta, harga beli listrik oleh PLN sebe- sar US $\$ 11,88$ cent $/ \mathrm{kWh}$ untuk kapasitas 35 MW. PLTSa Surakarta dan PLTSa DKI Jakarta sudah tahap konstruksi. PLTSa di Kota Palembang dan PLTSa di Kota Tangerang berada dalam tahap sudah ada pengembang. PLTSa sisanya berada dalam tahap lelang, Pre-Feasibility Study (Prastudi Kelayakan atau Pra-FS), Outline Business Case (Kajian Awal Prastudi Kelayakan, disingkat $\mathrm{OBC}$ ), atau Final Business Case (Kajian Akhir Prastudi Kelayakan, disingkat FBC). Seperti PLTSa Jatibarang Semarang saat ini dalam proses konsultasi penyusunan OBC. Jika semua proses lancar, diperkirakan pemenang lelang akan didapat pada Mei 2021 (Heviati, 2021b; Dewi, 2021).

\section{Kendala dan Permasalahan Pembangunan PLTSa}

Lambannya pembangunan PLTSa di 12 daerah dari program percepatan pembangunan PLTSa sesuai Peraturan Presiden Nomor 35 Tahun 2018 karena dihadapkan oleh banyak kendala dan permasalahan. Tabel 6 menjabarkan kendala dan permasalahan yang disampaikan beberapa sumber.

Berdasarkan berbagai sumber tersebut terlihat bahwa pengembangan PLTSa di Indonesia tidak hanya sebatas teknologi apa yang sebaiknya diterapkan, tetapi banyak hal yang menjadi kendala dan

Tabel 6.

\section{Kendala dan Permasalahan Pembangunan PLTSa}

\begin{tabular}{l} 
Kendala dan Permasalahan \\
\hline Elis Heviati (Direktorat Bioenergi, Dirjen EBTKE, Kementerian ESDM) (2021b) \\
- Adanya ketidakseragaman pembelian Biaya Layanan Pengolahan Sampah (BLPS) atau tipping fee pada tiap \\
daerah. Di Kota Surabaya tipping fee hanya Rp170.000,00/ton sampah, sedangkan di DKI Jakarta besarannya \\
hampir Rp600.000,00/ton sampah. Sementara itu, di Kota Surakarta zero tipping fee. \\
- Adanya persepsi yang kurang tepat dari pemerintah daerah bahwa penjualan listrik menggantikan kewajiban \\
pemerintah daerah untuk mengelola sampah di daerahnya melalui penyediaan BLPS. \\
- Minimnya alokasi APBD untuk kebersihan dan pengelolaan sampah. \\
- Kebersihan dan pengelolaan sampah masih belum menjadi program prioritas pemda. \\
- Kurangnya kemampuan dan pendanaan pemda untuk menyusun dokumen Pra-FS yang baik. Selain itu, aparat \\
pemda belum cukup familiar dalam melaksanakan pelelangan untuk mendapatkan Badan Usaha Pengelola/ \\
- Kengembang PLTSa. \\
- Karakteristik sampah di Indonesia yang tidak homogen/belum dilakukan pemilahan serta memiliki kadar air yang \\
- Skala bisnis yang menguntungkan secara ekonomis membutuhkan modal awal yang cukup besar dengan biaya \\
pengoperasian dan perawatan yang tinggi. \\
- Teknologi yang telah terbukti dan teruji sebagian besar masih bergantung dari luar negeri/impor.
\end{tabular}




\section{Kendala dan Permasalahan}

Andriah Feby Misna (Direktur Bioenergi Ditjen EBTKE Kementerian ESDM) (2020)

Sebagian besar proyek percepatan pengembangan PLTSa berada di daerah yang kebutuhan listriknya sudah

terpenuhi. Bahkan, beberapa daerah sudah mengembangkan PLTSa dengan teknologi nontermal, seperti:

1) Kota Semarang sudah mengembangkan PLTSa Jatibarang dengan memanfaatkan gas landfill (LFG), kapasitas listrik $800 \mathrm{kWh}$, harga pembelian tenaga listrik Rp1.119,00/kWh, masa kontrak 8 tahun, COD sejak 31 Desember 2020.

2) Kota Surabaya sudah mengembangkan PLTSa Benowo dengan memanfaatkan gas landfill (LFG), kapasitas 1,6 MW dan akan dinaikan menjadi 2 MW, COD sejak 2015, harga pembelian tenaga listrik untuk 1 unit Rp1.250,00/ kWh, masa kontrak 20 tahun.

Cita Dewi (Executive Vice-President Renewable Energy PLN) (2021)

- Kurangnya pendanaan proyek.

- Sulitnya pemilihan teknologi yang sesuai dengan dana yang tersedia.

- Optimalisasi kandungan lokal sulit dilakukan.

- Kendala perizinan dan pembebasan lahan untuk pembangunan PLTSa.

Sigit Sosiantomo (Anggota DPR RI Komisi V) (2021)

Harga beli listrik PLTSa program percepatan yang harus dibeli oleh PLN lebih tinggi daripada harga beli listrik PLTU berbahan bakar batu bara. Tingginya harga beli listrik PLN akan berpengaruh pada harga jualnya. Sementara itu, menaikkan tarif listrik sulit dilakukan. Kondisi ini berpotensi akan merugikan PLN karena kontrak PLTSa rata-rata di atas 20 tahun. PLN harus menanggung defisit dari harga listrik dalam jangka panjang.

Ari Bachtiar Krishna Putra (Laboratorium Rekayasa Thermal dan Sistem Energi DTM-FTIRS ITS) (2021)

- Komposisi sampah yang terbanyak adalah sampah organik.

- Sampah yang akan diolah tidak terpilah, dengan nilai kalor bervariatif, cenderung rendah akibat tingginya nilai kebasahan dan bahan non-combustible. Ketika sampah tidak terpilah tersebut masuk ke boiler akan merusak mesin. Sampah yang tidak terpilah terkontaminasi klorin, sulfur, merkuri, kadmium, dan logam berat lainnya sehingga perlu ada pre-treatment yang akan menambah biaya pengolahan sampah sebelum dikonversi menjadi energi listrik.

- Untuk PLTSa Benowo yang lokasinya di kelilingi kolam tambak, air bersih untuk membantu proses operasional PLTSa sulit didapat.

Kusmawatiningsih (Dinas Lingkungan Hidup Kota Bekasi) (21 Oktober 2020)

Pembangunan PLTSa di Kota Bekasi masih berkutat pada penentuan model kerja sama dan Feasibility Study Waste to Energy. Tidak adanya insentif dalam proses perizinan dan kerja sama, proses jual beli listrik yang rumit dan tidak jelas setiap tahapnya, menyulitkan pemerintah daerah untuk mengimplementasikan Perpres 35/2018.

Enri Damanhuri (Dosen Teknik Lingkungan Institut Teknologi Bandung) (2020)

- Sampah yang tidak terpilah dan dalam kondisi basah menjadikan nilai kalor rendah.

- Over estimasi terhadap potensi energi dari sampah yang berdampak terhadap membengkaknya biaya operasional dalam pengembangan WtE.

- Perencanaan pengembangan terkadang tidak diikuti dengan penyiapan SDM. Ditakutkannya PLTSa yang dibangun akan mangkrak karena tidak tersedianya/terbatasnya SDM yang mengoperasikannya.

Novrizal Tahar (Direktur Persampahan Ditjen PSLB KLHK) (2020)

- Anggaran pengelolaan sampah di daerah sangat kecil, idealnya 2\%-3\% dari APBD.

Surya Darma (Ketua Umum METI) (2020)

- Harga: Penetapan harga tidak berdasar keekonomian sehingga ada teknologi, lokasi, dan kapasitas yang tidak feasible.

- Pokok-pokok PJBL: tidak bankable, risiko tidak seimbang antara PLN dan pengembang, tingkat pengembalian pengembang menjadi tidak terjamin, yang berdampak tidak mendapatkan pendanaan dengan pola project finance.

- Menteri ESDM menegaskan tidak ada insentif untuk energi terbarukan sehingga energi terbarukan tidak bisa bersaing dengan fosil.

Rinaldy Dalimi (Dewan Pakar METI) (2020)

- Tingginya biaya investasi.

- Tidak adanya insentif bagi pengembang.

- Kurangnya kemauan politik untuk mengembangkan energi terbarukan.

Priyono Sutikno (Ketua Pusat Studi Pengembangan EBT ITB) (2020)

- Kurangnya dukungan sumber daya, baik anggaran, SDM, teknologi yang menjadikan pengembangan energi terbarukan, termasuk energi dari pemanfaatan sampah, kurang menarik bagi pasar.

- Kurangnya kemauan politik dari pemerintah untuk memprioritaskan pembangunan pembangkit dari energi terbarukan. 
permasalahan dalam proses pembangunannya. Pertama, pemilahan sampah dari sumber tidak dilakukan sehingga sampah yang akan menjadi bahan baku pembangkit dalam kondisi tercampur. Selain itu, sistem pengangkutan sampah yang sering kali masih dilakukan dengan truk bak terbuka menjadikan sampah basah. Sampah yang bercampur dan dalam kondisi basah nilai kalornya rendah dan perlu ada pre-treatment. Proses pre-treatment akan menambah biaya yang harus dikeluarkan dalam pengoperasian PLTSa. Menurut Damanhuri (2020), sampah kota itu tersusun dari komponen potensi energi yang sangat bervariasi. Ada yang nilai kalorinya tinggi (high heating value) dan ada yang rendah. Seperti sampah plastik, nilai kalornya dapat mencapai $11.000 \mathrm{kkal} /$ $\mathrm{kg}$, sisa makanan dapat mencapai 4.000 $\mathrm{kkal} / \mathrm{kg}$. Nilai kalor sebesar itu dapat dicapai jika sampah dalam keadaan kering. Inilah mengapa dalam pengembangan PLTSa, tidak hanya harus memperhitungkan sampah yang terpilah dari sumbernya, akan tetapi juga memperhitungkan proses pengumpulan dan pengangkutan sampah dilakukan yang dapat memastikan sampah selalu dalam kondisi tidak tercampur dan kering.

Kedua, sulitnya mencari teknologi yang sesuai dengan kondisi sampah yang ada dan sesuai dengan anggaran yang tersedia. Berbicara mengenai teknologi yang membutuhkan investasi besar dalam pengembangan PLTSa, BPPT saat ini sudah membangun PLTSa pilot project di Tempat Pengolahan Sampah Terpadu (TPST) Bantar Gebang, selanjutnya disebut PLTSa Bantar Gebang. Pilot project ini dibuat sebagai percontohan teknologi pengolahan sampah yang ramah lingkungan dengan bonus listrik serta dapat menyelesaikan permasalahan sampah secara tuntas (Pusat Teknologi Lingkungan Badan Pengkajian dan Penerapan Teknologi [PTL-BPPT], 2018, dalam Winanti, 2018: 66). PLTSa Bantar Gebang dibangun dengan memaksimalkan potensi dalam negeri, mulai dari engineering, fabrikasi (boiler furnace, waste bunker, water treatment plant, dan waste water treatment plant), dan konstruksi/sipil. Tingkat komponen dalam negeri (TKDN) PLTSa Bantar Gebang tercatat mencapai $65 \%$ dan sisanya impor seperti steam turbin dari India, grid lantai dari Cina (PTL-BPPT, 2020). Dengan TKDN mencapai 65\% diharapkan dapat mengurangi biaya investasi dalam pembangunan PLTSa (Winanti, wawancara, 23 Oktober 2020).

PLTSa Bantar Gebang merupakan instalasi pengolah sampah sistem termal yang menggunakan teknologi insinerasi, dengan kapasitas sampah terolah \pm 100 ton/hari, menggunakan bahan baku sampah dengan nilai kalor $1.500 \mathrm{kkal} / \mathrm{kg}$, pembakaran di dalam tungku dengan suhu $>850^{\circ} \mathrm{C}$ tanpa bahan bakar tambahan, dan output listrik $731,3 \mathrm{kWh}$ dengan 350 kWh-nya digunakan untuk pengoperasian PLTSa. Teknologi insinerasi yang dikembangkan PLTSa Bantar Gebang sudah disesuaikan dengan kondisi sampah yang ada pada umumnya di TPA di Indonesia, yaitu bercampur dan basah (Winanti, wawancara, 23 Oktober 2020). PLTSa Bantar Gebang terbukti mampu mereduksi sampah secara cepat, signifikan, ramah lingkungan, dengan bonus produksi listrik. Kekhawatiran akan polusi yang dihasilkan dari PLTSa berupa bottom ash dan fly ash tidak terbukti (PLT-BPPT, 2020).

Pembangunan PLTSa Bantar Gebang dari proses penyusunan desain, penyusunan AMDAL, persiapan dokumen lelang, proses lelang pembangunan PLTSa, ground breaking, konstruksi fisik, individual testing hingga pengoperasian rutin membutuhkan waktu sekitar 2 tahun (Oktober 2017 s.d Agustus 2019). Spesifikasi peralatannya meliputi bunker yang dilengkapi dengan platform dan crane, boiler yang memproduksi superheated steam dengan suhu $390^{\circ} \mathrm{C}$ dan tekanan $40 \mathrm{Bar}$, tungku bakar yang didesain dapat membakar sampah dengan suhu $\pm 850^{\circ} \mathrm{C}$ sehingga pembentukan dioxin diminimalisir, recip- 
rocating grate, turbin jenis total condensing, dan Air Pollution Control (APC) yang dilengkapi dengan water treatment plant (WTP) dan waste water treatment plant (WWTP) (PTL-BPPT, 2020). Total biaya pembangunan PLTSa Bantar Gebang dengan kapasitas maksimal 100 ton/hari dan output listrik 731,3 kWh adalah Rp88 miliar atau sekitar US\$6,24 juta. Dananya dari APBN. Kapasitas minimal yang harus diolah PLTSa agar mencapai break even point (BEP) adalah 1.000 ton/hari dengan output listrik 7,5 MW dan biaya pembangunan diperkirakan Rp880 miliar atau setara US\$62,12 juta (Winanti, wawancara, 23 Oktober 2020). Biaya yang sangat besar jika dibandingkan dengan anggaran pemerintah daerah untuk mengelola sampahnya. Namun, jauh lebih rendah dibandingkan perkiraan biaya investasi PLTSa di Kota Bekasi sebesar US\$53,3 juta untuk kapasitas 1,5 MW.

Ketiga, over estimasi potensi sampah untuk menghasilkan energi listrik. Sering kali pengembang dan pemerintah daerah tidak memperhitungkan kondisi sampah di Indonesia yang tidak terpilah, basah, dan memerlukan biaya pre-treatment yang cukup tinggi agar sampah dapat diproses di pembangkit listrik. Akibatnya, biaya Tipping Fee dan investasi membengkak. Tipping Fee yang besar akan memberatkan anggaran pemerintah daerah untuk pengelolaan sampah yang selama ini sebagian besar di bawah 0,5\% dari APBD (Tahar, 2020). Investasi yang besar akan memberatkan pengembang, apalagi tidak ada jaminan bankable bagi project financing (Darma, 2020; Kusumo, wawancara, 25 Februari 2020).

Over estimasi ini mungkin terjadi akibat dari adanya perbedaan terminologi dalam pengembangan PLTSa antara Kementerian ESDM dan KLHK. Kementerian ESDM menggunakan istilah PLTSa (Pembangkit Listrik Tenaga Sampah), sedangkan KLHK menggunakan istilah PSEL (Pengolah Sampah Energi Listrik). PLTSa lebih dimaknai sebagai pembangkit listrik, sedangkan
PSEL dimaknai sebagai instalasi pengolah sampah. Ketika PLTSa dimaknai sebagai pembangkit listrik, maka kebijakannya akan lebih diarahkan sebagaimana pembangkit listrik lainnya, yang lebih memperhitungkan berapa besar listrik yang dihasilkan. Regulasi yang diterapkan pun disejajarkan dengan regulasi pembangkit listrik energi terbarukan lainnya. Dalam hal ini, listrik dari sampah masuk dalam kategori energi terbarukan. Menjadi berbeda maknanya ketika digunakan istilah PSEL, instalasi PSEL merupakan bagian dalam proses pengelolaan sampah. Energi listrik yang dihasilkan dalam proses pengelolaan sampah adalah bonus dari upaya untuk mengurangi permasalahan lingkungan yang ditimbulkan oleh sampah. Itulah mengapa dalam program percepatan pengembangan PLTSa diarahkan untuk daerah-daerah dengan kondisi darurat sampah. Diharapkan melalui pembangunan PLTSa dengan teknologi termal, sampah kota dapat direduksi. Penempatan pembangunan PLTSa di daerah surplus listrik seharusnya tidak menjadi kendala ketika pemerintah daerah mempunyai komitmen yang kuat untuk mereduksi sampahnya.

Keempat, kurangnya kemauan politik dari pemerintah daerah, yang tercermin pada rendahnya anggaran daerah untuk pengelolaan sampah dan adanya persepsi bahwa penjualan listrik menggantikan kewajiban pemerintah daerah untuk mengelola sampahnya di daerah melalui penyediaan BLPS. Dalam persepsi pemerintah daerah, ketika PLTSa sudah beroperasi dan pemerintah daerah sudah membayarkan tipping fee, maka pengelolaan sampah menjadi tanggung jawab pengembang PLTSa (Heviati, 2021b). Dengan dibangunnya PLTSa di suatu daerah tidak melepaskan tanggung jawab pemerintah daerah dalam melakukan pengelolaan sampah di wilayahnya, sebagaimana diamanatkan dalam UU Pengelolaan Sampah. 
Kelima, keterbatasan SDM di daerah untuk mengembangkan PLTSa. SDM yang dibutuhkan dalam proses pengembangan PLTSa tidak hanya sebatas SDM untuk penyusunan Pra-FS, tetapi juga SDM untuk mengoperasikan lebih lanjut PLTSa. Inilah yang harus dipersiapkan setiap daerah yang akan mengembangkan PLTSa. Seperti pada kasus PLTSa Bantar Gebang yang ke depan akan diserahkan pengelolaannya dari BPPT kepada Pemda Provinsi DKI Jakarta. Proses transfer knowledge dilakukan oleh BPPT di sepanjang proses pembangunan PLTSa hingga PLTSa tersebut beroperasi dan berproduksi setiap hari sepanjang tahun (Winanti, wawancara, 23 Oktober 2020). Jika penyiapan SDM tidak dilakukan sejak awal, maka dapat dipastikan program percepatan pembangunan PLTSa ini pun akan mangkrak sebagaimana banyak program-program yang selama ini dilakukan pemerintah terkait dengan pemanfaatan teknologi.

Keenam, harga beli listrik PLTSa yang tinggi dibandingkan harga beli listrik dari pembangkit listrik berbahan bakar batu bara menjadikan proses menuju PJBL antara pengembang dengan PLN membutuhkan proses yang lama. Meskipun dalam Peraturan Presiden Nomor 35 Tahun
2018 secara jelas disebutkan bahwa PLN wajib membeli listrik yang dihasilkan dari program percepatan pembangunan PLTSa dengan harga yang sudah ditetapkan tanpa harus melalui negosiasi dan tanpa ada eskalasi (lihat Bagan 2). Namun dalam kenyataannya, Pemerintah Kota Bekasi mengalami kesulitan menuju proses PJBL. Proses menuju PJBL yang panjang, rumit, dan tidak jelas tahapannya menjadi kendala bagi Pemerintah Kota Bekasi dalam membangun PLTSa (Kusmawatiningsih, wawancara, 21 Oktober 2021), dan hal ini menjadi tidak menarik bagi investor. Proses panjang dan tidak jelas tahapannya merugikan bagi pengembang.

Diakui oleh PLN, bahwa harga beli listrik PLTSa program percepatan cukup mahal, yaitu US\$13,35 cent/kWh untuk kapasitas $\leq 20 \mathrm{MW}$ dan US\$14,54 dikurangi 0,076 kali kapasitas kontrak untuk kapasitas $\geq 20 \mathrm{MW}$. Sementara, harga beli listrik untuk pembangkit lainnya seperti PLTU yang berbahan bakar batu bara hanya berkisar US\$6-7 cent/kWh. Harga beli listrik yang lebih mahal dari PLTSa tentunya akan berakibat pada tingginya tarif listrik yang akan dikenakan oleh PLN. Jika harga beli listrik sebesar US\$13,35 cent/kWh, maka tarif listriknya menjadi Rp1.900,00/

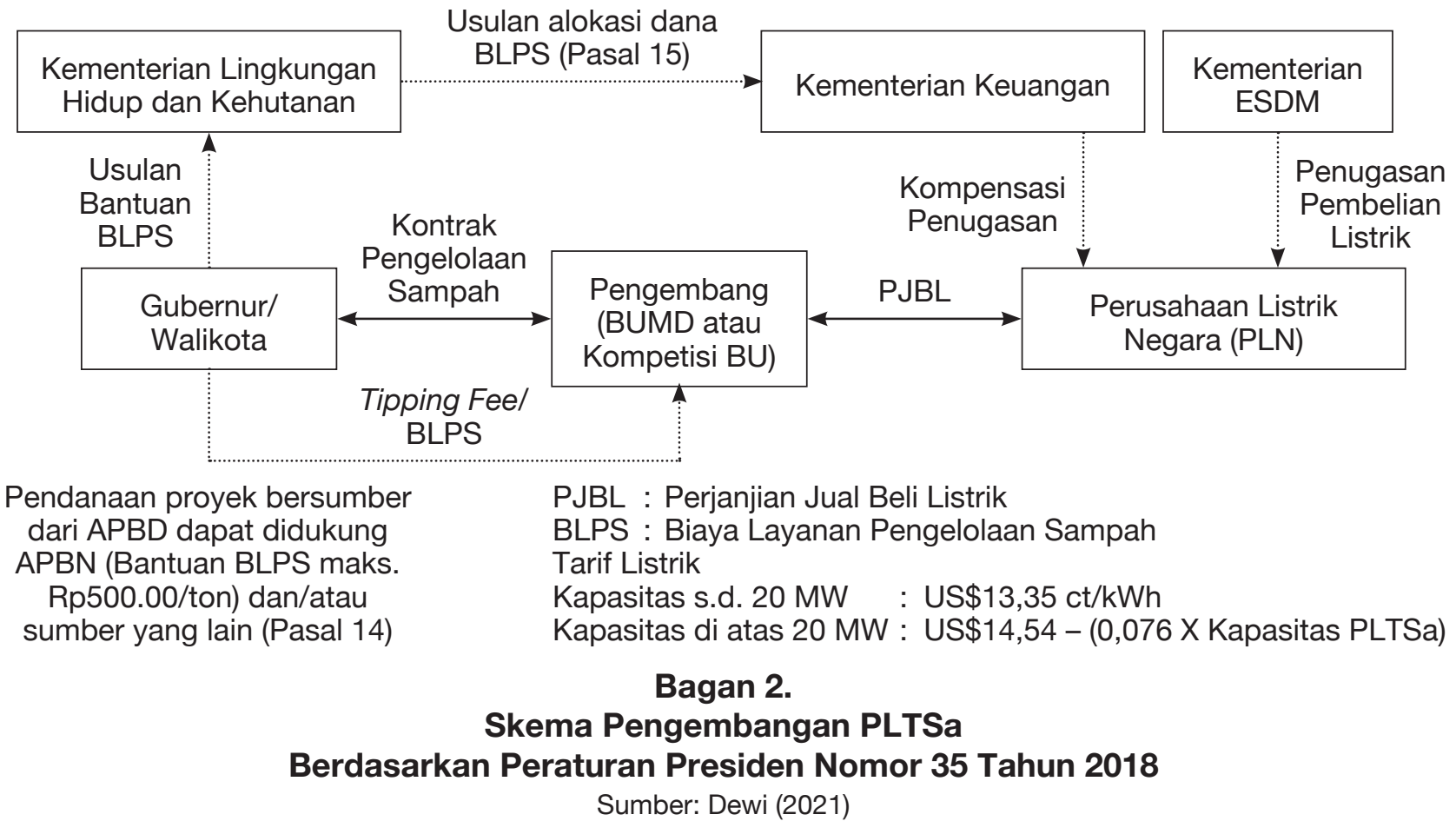


kWh. Sementara untuk harga beli listrik sebesar US\$6-7 cent/kWh, tarif listriknya antara Rp500,00 sampai Rp600,00/kWh. Namun, harga beli listrik PLTSa tersebut, menurut Direktur Utama PLN, Zulkifli Zaini, tidak membebani biaya pokok penyediaan (BPP) listrik PLN. Dengan di-mixed harga beli listrik dari pembangkit yang lain yang lebih murah, tarif listrik masih sekitar Rp1.400,00/kWh (Meilanova, 2021).

Ketujuh, tidak adanya insentif bagi pengembang PLTSa. Pengembang PLTSa berhak mendapatkan insentif dari pemerintah atau pemerintah daerah atas investasinya membangun PLTSa, sesuai amanat Pasal 20 dan 21 UU Energi. Namun pada kenyataannya, pengembang sulit menjaminkan pembangunan pembangkit listrik dari energi terbarukan, termasuk di dalamnya PLTSa, untuk mendapatkan pinjaman modal dari bank (Dalimi, 2020; Kusumo, wawancara, 25 Februari 2020). Dengan kata lain, investasi pada pembangunan PLTSa tidak bankable. Untuk itu, perlu ada political will dari pemerintah untuk memberikan jaminan kepada pengembang bahwa pembangunan PLTSa dapat dijaminkan untuk menambah modal. Ini sebagai salah satu bentuk insentif yang dapat diberikan kepada pengembang PLTSa.

Banyak hal yang harus dipersiapkan dalam pengembangan PLTSa, tidak hanya sebatas dana dan teknologinya. Pemerintah daerah yang akan mengembangkan PLTSa juga harus menyiapkan SDM yang mengoperasikannya, mengedukasi masyarakat untuk melakukan pemilahan, dan menyiapkan sarana prasarana pengumpulan dan pengangkutan sampah yang memadai sehingga sampah siap menjadi bahan baku pembangkit listrik tanpa perlu dilakukan pre-treatment dengan biaya tinggi. Pemerintah daerah harus memperhitungkan secara cermat potensi energi dari sampahnya. Di sisi lain, pemerintah pusat perlu menyiapkan regulasi yang mendukung bagi pengembangan PLTSa, seperti penetapan harga jual listrik
PLTSa yang bersaing, pemberian insentif bagi pengembang, dan memberikan jaminan bankable untuk investasi PLTSa. Jangan sampai kita mengalami kegagalan teknologi seperti India.

Kegagalan India dalam pengembangan PLTSa antara lain karena: karakteristik sampah yang kurang mendukung (sampah tidak terpilah); ketidakmampuan membayar/membiayai biaya operasi yang lengkap karena pendapatan dari jasa sarana ini tidak cukup untuk membayar pinjaman modal pembangunannya dan biaya operasi pemeliharaannya; kegagalan operasi dan pemeliharaan, termasuk tidak tersedianya pekerja yang terlatih; kelemahan dalam sistem manajemen; dan pengaturan aspek institusi yang belum memadai (Damanhuri, 2020).

Saat ini DPR RI, khususnya Komisi VII sedang menyusun RUU Energi Baru Terbarukan (RUU EBT), yang merupakan salah satu RUU prioritas Prolegnas tahun 2021. DPR dapat memberikan dukungan dalam pengembangan PLTSa ini dengan memasukkan beberapa hal, yaitu: mengenai penetapan harga jual listrik PLTSa, insentif bagi pengembang PLTSa, dan jaminan bankable bagi investasi PLTSa dalam draf RUU EBT.

\section{Penghasil Listrik atau Solusi Permasalahan Lingkungan?}

PLTSa adalah salah satu pembangkit listrik dari sumber energi terbarukan. Sumber energi terbarukan adalah sumber energi yang dihasilkan dari sumber daya energi yang berkelanjutan jika dikelola dengan baik, seperti panas bumi, angin, bioenergi, sinar matahari, aliran dan terjunan air, gerakan dan perbedaan suhu lapisan laut (Kementerian ESDM, 2014: 2). Pemanfaatan sampah untuk energi listrik dalam perkembangan pembangkit listrik energi terbarukan sudah lama dilakukan. Berdasarkan data Direktorat Jenderal Ketenagalistrikan Kementerian Energi dan Sumber Daya Mineral (Ditjen Gatrik KESDM), pemanfaatan sampah untuk 
energi listrik sudah dilakukan sejak tahun 2014. Kapasitas terpasang PLTSa di tahun 2014 adalah 14,00 MW, di mana kapasitas terpasang pembangkit listrik nasional di tahun yang sama secara keseluruhan pembangkit adalah 50,417 GW. Hingga tahun 2018, kapasitas terpasang PLTSa tidak mengalami peningkatan signifikan, hanya $0,02 \%$ dari keseluruhan pembangkit listrik yang terbangun sebesar 64,92 GW (Ditjen Gatrik KESDM, 2019: 7-8).

Jika dibandingkan dengan pembangkit listrik dari sumber energi terbarukan lainnya, sumbangan listrik yang diberikan PLTSa tidaklah terlalu besar. Bahkan, penambahan kapasitasnya cenderung tidak ada peningkatan, seperti yang terlihat dalam Tabel 7. Sumbangan PLTSa untuk listrik nasional pun kecil sehingga PLTSa bisa dikatakan sulit jika diharapkan untuk membantu pencapaian target $23 \%$ bauran pembangkitan dari energi terbarukan pada tahun 2025 (Winanti, wawancara, 23 Oktober 2020).

Lalu, bagaimana sumbangan PLTSa untuk mereduksi timbulan sampah? Jika mengacu pada apa yang sudah dilakukan PLTSa Bantar Gebang, PLTSa dengan teknologi termal insinerasi mampu mereduksi sampah yang masuk ke TPST Bantar Gebang 100 ton per hari. Sampah yang diolah di PLTSa Bantar Gebang tidak hanya sampah yang masuk ke TPST, tetapi juga sampah yang ada di landfill TPST (Winanti, wawancara, 23 Oktober 2020). PLTSa dengan teknologi termal telah terbukti dapat mengurangi timbulan sampah dan tidak berdampak terhadap lingkungan. Bahkan, teknologi insinerasi mampu mereduksi sampah hingga 1.300 ton per hari, jauh lebih tinggi jika dibanding teknologi termal lainnya. Teknologi pirolisis kapasitas sampah yang tereduksi hanya 70-270 ton per hari dan gasifikasi 900 ton per hari (The International Solid Waste Association [ISWA], 2013: 12-19).

Beberapa negara yang telah berhasil mengurangi sampahnya dengan membangun PLTSa termal, antara lain: Eropa,
Amerika Utara, Singapura, dan Jepang. Pembangkit yang paling banyak digunakan adalah PLTSa termal insinerasi, yaitu lebih dari 1.000 pembangkit sudah dibangun di dunia. Sementara PLTSa termal dengan teknologi gasifikasi kurang dari 150 pembangkit, dan PLTSa termal dengan teknologi pirolisis kurang dari 10 pembangkit (KESDM, 2016 dalam Hanif, 2018: 140). Oleh karena itu, PLTSa termal lebih tepat menjadi solusi instan bagi kota-kota besar dengan produksi sampah di atas 1.000 ton per hari dan mengalami kesulitan dalam menyediakan lahan untuk TPA. Untuk jangka panjangnya, upaya mereduksi sampah melalui 3R (reduce, reuse, dan recycle) tetap harus dilakukan. Mengingat pemilahan sampah juga sangat diperlukan dalam pengoperasian PLTSa. Pemilahan sampah dapat mengoptimalkan energi listrik yang dihasilkan dari PLTSa.

\section{Penutup}

PLTSa merupakan alternatif sumber energi terbarukan untuk memenuhi kebutuhan listrik masyarakat. Sumber energi terbarukan yang ramah lingkungan dan berkelanjutan. Selain itu, pembangunan PLTSa juga merupakan upaya untuk mengatasi permasalahan sampah di kota-kota besar yang telah dihadapkan pada keterbatasan lahan untuk menyediakan TPA dan pencemaran lingkungan dari sampah TPA yang tidak terkelola dengan baik. Upaya percepatan pembangunan PLTSa, terutama di 12 daerah dengan permasalahan persampahan yang kompleks, dilakukan pemerintah dengan menerbitkan Peraturan Presiden Nomor 35 Tahun 2018. Namun, pembangunan PLTSa di 12 daerah pada kenyataannya belum juga terwujud. Baru PLTSa Kota Surabaya yang sudah beroperasi secara komersial per 6 Mei 2021. PLTSa di DKI Jakarta dan PLTSa di Surakarta dalam tahap konstruksi. PLTSa di Palembang dan di Tangerang dalam tahap sudah ada pengembang. PLTSa sisanya berada dalam tahap lelang, Pra-FS, OBC, ataupun FBC. 
Tabel 7.

Perkembangan Pembangkit Listrik Bersumber Energi Terbarukan Berdasarkan Kapasitas Terpasang (MW), 2014-2018

\begin{tabular}{lrrrrr}
\hline Jenis Tenaga Pembangkit Listrik & \multicolumn{1}{c}{$\mathbf{2 0 1 4}$} & $\mathbf{2 0 1 5}$ & $\mathbf{2 0 1 6}$ & \multicolumn{1}{c}{$\mathbf{2 0 1 7}$} & \multicolumn{1}{c}{$\mathbf{2 0 1 8}$} \\
\hline Pembangkit Listrik Tenaga Air & $5.018,59$ & $5.038,59$ & $5.313,59$ & $5.313,59$ & $5.369,59$ \\
Pembangkit Listrik Tenaga Minihidro & 111,26 & 148,71 & 211,40 & 240,55 & 267,79 \\
Pembangkit Listrik Tenaga Mikrohidro & 76,95 & 90,15 & 95,87 & 103,76 & 104,76 \\
Pembangkit Listrik Tenaga Bayu & 1,46 & 1,46 & 1,46 & 1,46 & 143,51 \\
Pembangkit Listrik Tenaga Biogas & 28,80 & 54,72 & 64,16 & 100,64 & 108,62 \\
Pembangkit Listrik Tenaga Biomassa & $1.359,87$ & $1.671,29$ & $1.703,29$ & $1.740,54$ & $1.757,54$ \\
Pembangkit Listrik Tenaga Panas Bumi & $1,403,30$ & $1.438,30$ & $1.533,30$ & $1.808,30$ & $1.948,30$ \\
Pembangkit Listrik Tenaga Surya & 22,74 & 33,36 & 43,12 & 50,90 & 60,19 \\
Pembangkit Listrik Tenaga Sampah & 14,00 & 15,65 & 15,65 & 15,65 & 15,65 \\
Pembangkit Listrik Tenaga Hybrid & 0,08 & 3,58 & 3,58 & 3,58 & 3,58 \\
\hline
\end{tabular}

Sumber: Ditjen Gatrik KESDM (2019: 11-12)

Lambannya pembangunan PLTSa dihadapkan pada banyak kendala, yaitu: tingginya tipping fee akibat sampah tidak terpilah dan basah sehingga perlu ada pretreatment, anggaran pemerintah daerah terbatas sehingga sulit memilih teknologi yang sesuai dengan anggaran dan kondisi sampah yang ada, over estimasi atas potensi listrik dari sampah yang merugikan pengembang dan pemerintah daerah, rendahnya kemauan politik pemerintah daerah yang tercermin dari rendahnya anggaran daerah untuk pengelolaan sampah, keterbatasan SDM sesuai kapasitas yang dibutuhkan untuk pengembangan PLTSa, tingginya harga jual listrik PLTSa dibandingkan listrik dari batu bara, tidak adanya insentif bagi pengembang, dan pembangunan PLTSa tidak bankable.

Sampah dapat menjadi sumber energi terbarukan. Namun, PLTSa sebagai penghasil energi listrik tidak dapat disejajarkan dengan pembangkit listrik energi terbarukan lainnya. PLTSa dengan teknologi termal lebih merupakan instalasi pengolah sampah yang menghasilkan listrik sebagai bonusnya. PLTSa teknologi termal, terutama yang menggunakan teknologi insinerasi, mampu mereduksi sampah dengan cepat dan jumlah cukup besar. Pembangunan PLTSa termal dapat menjadi solusi instan bagi daerah dengan produksi sampah yang banyak (di atas 1.000 ton per hari) dan memiliki kendala dalam menyediakan lahan untuk TPA.

Dalam rangka pengembangan PLTSa dan mengatasi masalah persampahan kota-kota besar, maka ke depan perlu ada: (1) dukungan regulasi mengenai harga jual listrik PLTSa, insentif bagi pengembang PLTSa, dan jaminan bankable untuk investasi PLTSa; (2) menghitung secara cermat potensi energi dari sampah; (3) mengalokasikan anggaran minimal 2-3\% dari APBD untuk pengelolaan sampah; (4) menyiapkan SDM yang mempunyai kemampuan untuk mengope-rasikan PLTSa; (5) mengedukasi masyarakat untuk melakukan pemilahan sampah; dan (6) menyiapkan sarana prasarana pengumpulan dan pengangkutan sampah yang memadai agar sampah siap menjadi bahan baku pembangkit listrik tanpa perlu pretreatment dengan biaya tinggi. DPR saat ini sedang menyusun RUU Energi Baru Terbarukan (RUU EBT). Regulasi mengenai penetapan harga jual listrik PLTSa, insentif bagi pengembang PLTSa, dan jaminan bankable untuk investasi PLTSa dapat dipertimbangkan untuk masuk dalam RUU EBT. 


\section{Daftar Pustaka}

Ali, J., Rasheed, T., Afreen, M., Anwar, M. T., Nawaz, Z., Anwar, J., \& Rizwan, K. (2020). Modalities for conversion of waste to energy - Challenges and perspectives. Science of Total Environment, 727(2020), 138610. doi: 10.1016/j. scitotenv.2020.138610

Ashworth, D. C., Elliott, P., \& Toledano, M.B. (2014). Waste incineration and adverse birth and neonatal outcomes: a systematic review. Environment International. 69, 120-132. doi: 10.1016/j. envint.2014.04.003 Diakses dari https:// www.sciencedirect.com/science/article/ pii/S0160412014001147

Badan Pusat Statistik. (2018). Statistik Lingkungan Hidup Indonesia 2018. Jakarta: Badan Pusat Statistik.

Badan Pusat Statistik. (2019, September 24). Emisi Gas Rumah Kaca Menurut Jenis Sektor (Ribu Ton CO2e), 2001-2017. Diakses dari https://www.bps.go.id/ statictable/2019/09/24/2072/emisi-gasrumah-kaca-menurut-jenis-sektor-ributon-co2e-2001-2017.html

Bosman, A., \& Helsen, L. (2010, November 8-11). Energy from waste: review of thermochemical technologies for refuse derived fuel (RDF) treatment. Dalam the International Symposium on Energy from Biomass and Waste, Venice, Italy.

Dalimi, R. (2020, Maret 3). Optimalisasi Pengembangan Energi Terbarukan [Paparan]. Focus Group Discussion Penelitian Kelompok Pusat Penelitian Badan Keahlian DPR RI tentang Optimalisasi Pengembangan Energi Baru Terbarukan, Jakarta. Tidak diterbitkan.

Damanhuri, E. (2020, Juli 28). Regulasi dan Implementasi Waste to Energy [Paparan]. Seminar Nasional Waste to Energy in Kalimantan dan FGD Rencana Pembangunan PLTSa Kota Pontianak. Pemerintah Kota Pontianak bekerja sama dengan Universitas Tanjungpura, Pontianak. Tidak diterbitkan.

Darma, S. (2020, Maret 3). Tantangan Pengembangan Energi Terbarukan dan
Penataan Ulang Regulasi untuk Percepatan Investasi ET [Paparan]. Focus Group Discussion Penelitian Kelompok Pusat Penelitian Badan Keahlian DPR RI tentang Optimalisasi Pengembangan Energi Baru Terbarukan, Jakarta. Tidak diterbitkan.

Dewi, C. (2021, Februari 6). Peran Serta PLN dalam Mendukung PLTSa [Paparan]. Webinar Teknik Mesin ITS dengan tema Pembangkit Listrik Tenaga Sampah (PLTSa): Tantangan, Kendala, dan Peluang, Surabaya. Tidak diterbitkan.

Direktorat Jenderal Ketenagalistrikan Kementerian Energi dan Sumber Daya Mineral. (2019). Statistik Ketenagalistrikan Tahun 2018, (32) Tahun Anggaran 2019. Jakarta: Sekretariat Jenderal Ketenagalistrikan.

Dodi, N., Syafii, \& Raharjo, S. (2015). Studi Kajian Kelayakan Pembangunan Listrik Tenaga Sampah (PLTSa) Kota Padang (Studi Kajian di TPA Air Dingin Kota Padang). Jurnal Teknik Elektro, 4(2), 24-33.

Ekky, T. (2019). Tipping fee determination to support the waste to energy concept at the city of Depok, Indonesia. Dalam E3S Web of Conference, 90, 01007. EDP Sciences. doi: 10/1051/e3sconf/20199001007

Faruq, U. I. (2016). Studi potensi limbah kota sebagai pembangkit listrik tenaga sampah (PLTSa) Kota Singkawang. Jurnal Teknik Elektro Universitas Tanjungpura, 2(1). Diakses dari https://media.neliti.com/ media/publications/192112-ID-studipotensi-limbah-kota-sebagai-pemban.pdf

Hanif, M. (2018). Aplikasi Teknologi Termal Untuk Pengolahan Sampah. Dalam Prosiding Seminar Nasional dan Konsultasi Teknologi Lingkungan. Pusat Teknologi Lingkungan Badan Pengkajian dan Penerapan Teknologi. Diakses dari https://enviro.bppt.go.id/ Publikasi/ProsidingTekLing 2018/ ProcedingTekLing2018.html

Heviati, E. (2021a, Februari 6). Pengelolaan Sampah Menjadi Energi [Paparan]. Webinar Teknik Mesin ITS dengan tema Pembangkit Listrik Tenaga Sampah (PLTSa): Tantangan, Kendala, dan Peluang, Surabaya. Tidak diterbitkan. 
Heviati, E. (2021b, Februari 6). Webinar renewable energy: pembangkit listrik tenaga sampah [Video file]. Diakses dari https://www.youtube.com/ watch? $v=$ fp1oyrcOJXU

Hossain, H. M. Z., Hossain, Q. H., Monir, M. M., \& Ahmed, M. T. (2014). Municipal solid waste (MSW) as a source of renewable energy in Bangladesh: revisited. Renewable and Sustainable Energy Reviews, 10, 11-21. doi: 10.1016/j. rser.2014.07.007

Hutabarat, I. N., Priyambada, I. B., Samudro, G., Lokahita, B., Syafrudin, Wardhana, I. W., \& Hadiwidodo, M. (2018). Potensi material sampah combustible pada zona pasif TPA Jatibarang Semarang sebagai bahan baku RDF (refuse derived fuel). Jurnal Teknik Mesin Mercu Buana, 7(1), 24-28.

Ikhsan, R., \& Syukriyadin. (2014). Studi Kelayakan Pembangunan Pembangkit Listrik Tenaga Sampah (PLTSa) di TPA Kota Banda Aceh. Dalam F. Arnia, Zulhelmi, \& M. Syaryadhi (Ed.), Prosiding Seminar Nasional Expo dan Teknik Elektro, Medan, Sumatera Utara (hal. 146-151). Universitas Syiah Kuala dan Politeknik Negeri Medan.

Indonesian Center for Environmental Law. (2018, September 30). Jokowi Harus Stop Pembangunan PLTSa Sunter Jakarta. Diakses dari https://icel.or.id/ tak-berkategori/jokowi-harus-stoppembangunan-pltsa-sunter-jakarta/

Indonesian Center for Environmental Law. (2019, Agustus, 26). PLTSa di tengah Pusaran Energi Terbarukan. Diakses dari https://icel.or.id/isu/pltsa-di-tengahpusaran-energi-terbarukan/

Kementerian Lingkungan Hidup dan Kehutanan. (2017). Strategi Implementasi NDC (Nationally Determined Contribution). Jakarta: Direktorat Jenderal Pengendalian Perubahan Iklim Kementerian Lingkungan Hidup dan Kehutanan.

Kokossis, A. C., Tsakalova, M., \& Pyrgakis, K. (2015). Design of integrated biorefineries. Computers \& Chemical Engineering, 81, 40-56. doi: 10.106/j. compchemeng.2015.05.021
Kusmawatingsih. (2020, Oktober 21). Optimalisasi Pengembangan Energi Baru Terbarukan/Pewawancara: Tim Penelitian Kelompok Optimalisasi Pengembangan Energi Baru Terbarukan, Pusat Penelitian Badan Keahlian DPR RI, Jakarta.

Kusumo, R. (2020, Februari 25). Optimalisasi Pengembangan Energi Baru Terbarukan/ Pewawancara: Tim Penelitian Kelompok Optimalisasi Pengembangan Energi Baru Terbarukan, Pusat Penelitian Badan Keahlian DPR RI, Jakarta.

Mantovani, C. (2020, Desember 22). Dekat Permukiman Warga, PLTSa Putri Cempo Mojosongo Solo Masalah atau Solusi?. SoloPos. Diakses dari https://www. solopos.com/dekat-permukiman-wargapltsa-putri-cempo-mojosongo-solomasalah-atau-solusi-1098572

Meilanova, D. R. (2021, Mei, 18). PLN Siap Beli Listrik dari Pembangkit Tenaga Sampah. Bisnis.com. Diakses dari https://ekonomi. bisnis.com/read/20210518/44/1395095/ pln-siap-beli-listrik-dari-pembangkittenaga-sampah, pada 12 Mei, 2021.

Misna, A. F. (2020, Juli 28). Regulasi dan Implementasi Waste to Energy [Paparan]. Seminar Nasional Waste to Energy in Kalimantan dan FGD Rencana Pembangunan PLTSa Kota Pontianak. Pemerintah Kota Pontianak bekerja sama dengan Universitas Tanjungpura, Pontianak. Tidak diterbitkan.

Mubeen, I., \& Buekens, A. (2019). Chapter 14 - Energy from Waste: Future Prospects Toward Sustainable Development, dalam S. Kumar, R. Kumar, A. Pandey (ed.), Current Development in Biotechnology and Bioengineering (hal. 283-305). Elsevier. doi: 10.1016/B978-0-444-64083-3.000142

Nizami, A. S., Rehan, M., Waqas, M., Naqvi, M., Ouda, O. K. M., Shahzad, K., Miandad, R., Khan, M. Z., Syamsiro, M., Ismail, I. M. I., \& Pant, D. (2017). Waste biorefineries: Enabling circular economies in developing countries. Bioresource Technology, 241 (October 2017), 1101-1117. doi: 10.1016/j. biortech.2017.05.097

Nurdiansah, T., Purnomo, E. P., \& Kasiwi, A. (2020). Implementasi Pembangkit Listrik 
Tenaga Sampah (PLTSa) sebagai Solusi Permasalahan Sampah Perkotaan: Studi Kasus di Kota Surabaya. ENVIROTEK: Jurnal IImiah Teknik Lingkungan, 12(1), 8792. doi: 10.33005/envirotek.v12i1.47

Paleologos, E.K., Caratelli, P., \& Amrousi, M.E. (2016). Waste-to-Energy: an opportunity for a new industrial typology in Abu Dhabi. Renewable and Sustainable Energy Reviews, 55, 1260-1266. doi: 10.1016/j. rser.2015.07.098

Peraturan Pemerintah Nomor 79 Tahun 2014 tentang Kebijakan Energi Nasional. (2014).

Peraturan Presiden RI Nomor 97 Tahun 2017 tentang Kebijakan dan Strategi Nasional Pengelolaan Sampah Rumah Tangga dan Sampah Sejenis Sampah Rumah Tangga. (2017).

Pusat Teknologi Lingkungan Badan Pengkajian dan Penerapan Teknologi. (2020, Oktober 23). PLTSa/PSEL Pengolahan Sampah Teknologi Termal [Paparan]. Focus Group Discussion Penelitian Kelompok Pusat Penelitian Badan Keahlian DPR RI tentang Optimalisasi Pengembangan Energi Baru Terbarukan, Jakarta.

Putra, A. B. K. [Institut Tekologi Sepuluh Nopember]. (2021, Februari 6). Webinar renewable energy: pembangkit listrik tenaga sampah [Video file]. Diakses dari https://www.youtube.com/ watch?=fp1oyrcOJXU

Safrizal (2014). Distributed Generation Pembangkit Listrik Tenaga Sampah Kota (PLTSa) Type Incinerator Solusi Listrik Alternatif Kota Medan. Prosiding Seminar Nasional Teknologi dan Informatika Ke-1 Tahun 2014, Fakultas Teknik Universitas Kudus, Kudus, Agustus 2014, 121-128.

Sosiantomo, S. [Institut Tekologi Sepuluh Nopember]. (2021, Februari 6). Webinar renewable energy: pembangkit listrik tenaga sampah [Video file]. Diakses dari https://www.youtube.com/ watch?=fp1oyrcOJXU

Suhada, R. T., \& Almahdy, I. (2017). Analisis Potensi Sampah sebagai Sumber Pembangkit Listrik Tenaga Sampah dan Produk Kreatif untuk Mendukung Pariwisata (Studi Kasus di Kepulauan
Seribu). Jurnal Penelitian dan Aplikasi Sistem dan Teknik Industri, 11(3), 245-255.

Suparman, F. (2020, Maret 6). KPK Nilai PLTSa sebagai Pemborosan APBN. Beritasatu. com. Diakses dari https://www.beritasatu. com/ekonomi/606181/kpk-nilai-pltsasebagai-pemborosan-apbn

Sutikno, P. (2020, September 10). Persembahan ITB: Energi untuk Indonesia [Paparan]. Focus Group Discussion Penelitian Kelompok Pusat Penelitian Badan Keahlian DPR RI tentang Optimalisasi Pengembangan Energi Baru Terbarukan. Jakarta.

Tahar, N. [Diskominfo Kota Pontianak]. (2020, Juli 28). Waste to energy in Kalimantan \& FGD rencana pembangunan PLTSaWebinar Seminar Nasional [Video file]. Diakses dari https://www.youtube.com/ watch?=TdsA7a3k6Jo

The International Solid Waste Association. (2013). White Paper - Alternative Waste Conversion Technologies. The International Solid Waste Association. Diakses dari https://www.iswa.org/ knowledge-base/iswa-white-paperon-alternative-waste-conversiontechnologies $/ \mathrm{v}=\mathrm{b} 718 \mathrm{adec} 73 \mathrm{e} 0$

Themelis, N., \& Ulloa P. (2005). Capture and Utilisation of Landfill Gas. Renewable Energy, 77-81. Diakses dari https://www. researchgate.net/publication/237368895_ Capture_and_Utilisation_of_Landfill_Gas

Wahana Lingkungan Hidup Indonesia. (2018, Mei 31). Perpres No.35/2018 tentang PLTSa: Pemaksaan Teknologi Mahal dan Tidak Berkelanjutan [Press Release]. Diakses dari https://www.walhi.or.id/ perpres-no-35-2018-tentang-pltsapemaksaan-teknologi-mahal-dan-tidakberkelanjutan

Wibby, P. (2020, Desember 11). Rencana Pembangunan PLTSa di Semarang dan Surakarta, Ini Pendapat Walhi. Serat id. Diakses dari https://serat.id/2020/12/11/ rencana-pembangunan-pltsa-disemarangg-dan-surakarta-ini-pendapatwalhi/

Winanti, W. S. (2018, September 20). Teknologi Pembangkit Listrik Tenaga Sampah 
(PLTSa). Prosiding Seminar Nasional dan Konsultasi Teknologi Lingkungan, 65-72. Jakarta: BPPT.

Winanti, W. S. (2020). Optimalisasi Pengembangan Energi Baru Terbarukan/ Pewawancara: Tim Penelitian Kelompok Optimalisasi Pengembangan Energi Baru Terbarukan, Pusat Penelitian Badan Keahlian DPR RI, Jakarta. 